\title{
PENGEMBANGAN USAHA MIKRO KECIL DAN MENENGAH (UMKM) KERAJINAN MENJAHIT DAN BORDIR DI KECAMATAN MEDAN AREA KOTA MEDAN
}

\author{
Prihatin Lumbanraja $^{1 *}$, Arlina Nurbaity Lubis ${ }^{1}$, Sitti Raha Agoes Salim ${ }^{1}$ \\ ${ }^{1}$ Fakultas Ekonomi dan Bisnis USU \\ *email: titinlumbanraja@yahoo.com
}

\begin{abstract}
Abstrak
Kegiatan pengabdian pada masyarakat ini bertujuan untuk mengembangkan usaha mikro dalam upaya peningkatan daya saing usaha untuk menggerakkan roda perekonomian Indonesia. Dalam kegiatan ini, pengabdian ditujukan kepada kelompok usaha kreatif yang bergerak dalam usaha pembordiran dan penjahit pakaian. Situasi saat ini menunjukkan bahwa pengaplikasiakn konsep-konsep manajemen, khususnya manajemen usaha, pemasaran, serta penenuan harga masih belum sesuai dari kondisi ideal. Situasi ini memberikan peluang optimalisasi kegiatan usaha jika UMKM berhasil dibina dengan baik.

Kegiatan pengabdian dilakukan dalam bentuk sumbangan mesin jahit serta material lainnya yang ditujukan untuk peningkatan produksi dan pelatihan keterampilan pengusaha UMKM anggota kelompok mitra. Pelatih didatangkan secara berkala untuk meningkatkan keterampilan pengusaha yang nantinya akan membantu anggota UMKM lainnya. Penyuluhan diberikan agar pengusaha lebih memahami konsep dan pengaplikasian manajemen dalam kegiatan usaha. Pendampingan diberikan agar penyerapan dan perubahan sikap menjadi lebih optimal. Evaluasi dilakukan untuk melihat perkembangan pengelola UMKM setelah menerika rangkaian kegiatan pengabdian.

Hasil yang diperoleh setelah menyelesaikan rangkaian kegiatan pengabdian tergolong memuaskan. Mitra mengalami perubahan mendasar dari berbagai aspek dan menjadi lebih baik dalam mengelola usaha.
\end{abstract}

Kata Kunci: Daya Saing Usaha, Manajemen, Pemasaran, Penentuan Harga

\section{PENDAHULUAN}

Sektor usaha kecil dan menengah memegang peranan yang sangat penting dalam membangun perekonomian masyarakat. Hal ini terutama bila dikaitkan dengan pemberdayaan ekonomi masyarakat dan jumlah tenaga kerja yang mampu diserap oleh usaha kecil dan menengah tersebut. Selain memiliki arti strategis bagi pembangunan, usaha kecil menengah juga berfungsi sebagai sarana untuk memeratakan hasil-hasil pembangunan yang telah dicapai.

Dalam rangka mengaplikasikan tridarma perguruan tinggi dilakukan pengabdian kepada masyarakat yang menggeluti usaha kreatif diantaranya masyarakat yang menekuni kerajinan menjahit dan bordir. Pengabdian ini ditujukan kepada usaha kreatif dibidang seni yang menghasilkan beragam produk diantaranya: pakaian, taplak meja, tempat tisu dan lainlain. Salah satu yang menjadi daya tarik dalam pemilihan bidang ini adalah semakin meningkatnya peminat terhadap produk bordir, yang dapat dilihat diantaranya melalui trend fashion dimana saat ini keberadaan bordir pada pakaian tidak hanya didominasi oleh wanita.Akan tetapi kenyataannya bordir juga digemari oleh kalangan pria. Kondisi ini memunculkan minat masyarakat untuk menekuni keterampilan jahit menjahit dan bordir. Para pengerajin ini pada awalnya bekerja untuk perusahaan-perusahaan besar. Akan tetapi seiring berkembangnya minat masyarakat terkait dengan produk bordir serta keinginan dari pengerajin untuk berkembang dan meningkatkan pendapatannya, maka pengerajin mulai membentuk kelompokkelompok kecil yang mandiri.

Mitra pengabdian adalah dua kelompok kecil yang berada di Kota Matsum, Medan Area, yaitu Kelompok Tulip Kreasi Jl. Mansun No. 4/5 Medan Lingkungan VIII Kel. Komat 4, Kec. Medan Area (Hajjah Misiani); dan Kelompok Komat Bordir Jl. Amaliun No. 34/68 Medan Lingkungan IX Kel. Komat 4, Kec. Medan Area (Ibu Ratnasari). Kedua kelompok ini memasarkan keahliannya dalam 
Lumbanraja, P. et al. Pengembangan Usaha Mikro Kecil dan Menengah (UMKM) Kerajinan Menjahit dan...

menjahit dan membuat bordir masih dari mulut ke mulut. Selama ini mereka belum menghasilkan produk sendiri hanya menerima pesanan untuk jahitan dan bordir.

Saat ini permasalahan mitra dalam menjalankan usahanya antara lain : mereka belum menghasilkan produk sendiri hanya menerima pesanan untuk jahitan dan bordir. Dalam bidang pengelolaannya, mitra belum pernah membuat perencanaan bisnis, laporan keuangan dan menghitung biaya produksi, serta tidak mengetahui bagaimana merancang strategi pemasaran yang tepat. Disamping itu, mereka juga memiliki keterbatasan dalam peralatan, permodalan dan teknologi, sehingga aktivitas penjahitan dan pembordiran belum menggunakan mesin yang mengikuti perkembangan teknologi. Di samping itu, berdasarkan hasil pra-survei yang dilakukan masih ditemukan perlunya perbaikan kualitas produk baik dilihat dari kerapihan, daya tahan dan motif yang lebih sesuai dengan selera konsumen, sehingga dapat meningkatkan daya saing.

Solusi yang diberikan dalam upaya peningkatan kuantitas dan kualitas produk akan diberikan bantuan berupa mesin bordir dengan spesifikasi yang lengkap dan terbaru untuk meningkatkan daya saing. Akan diberikan penyuluhan terkait dengan peningkatan kemampuan pengelolaan usaha, strategi pemasaran dan penyusunan laporan keuangan serta menghitung harga pokok produksi.

\section{METODE PENGABDIAN}

Kegiatan pengabdian dilakukan dengan memberikan kerjasama kepada mitra dan kelompoknya. Aktivitas pengabdian dimulai dengan diskusi kelompok untuk memetakan akar permasalahan yang dihadapi oleh mitra berikut rencana penyelesaian masalah yang dihadapi mitra.

Peningkatan produksi jahit dan bordir dilakukan dengan memberikan mesin bordir dan peralatan jahit menjahit dengan teknologi yang lebih mutakhir. Peningkatan kemampuan pemasaran dapat dilakukan dengan memberikan pelatihan/penyuluhan dan pendampingan kepada kelompok usaha jahit dan bordir. Tim pengabdian mendatangkan pelatih selama dua bulan untuk meningkatkan kapasitas dan kapabilitas keterampilan mitra dan anggota

kelompoknya.

Kegiatan yang dilakukan untuk pemecahan masalah mitra adalah dengan tahapan sebagai berikut :

1. Pemberian 2 unit mesin bordir, dengan tujuan peningkatan produktivitas dan sarana berlatih bagi mitra dan anggotanya yang selama ini dirasakan kurang.

2. Pemberian peralatan jahit menjahit jarum pentul, radar, gunting, ram, dan sebagainya, dengan tujuan sebagai peralatan pendukung pelatihan dalam upaya peningkatan keterampilan mitra.

3. Pelatihan peningkatan keterampilan mitra dan anggotanya dengan mendatangkan pelatih selama 2 bulan, dengan tujuan penyerapan ilmu dari pengerajin yang lebih terampil.

4. Pelatihan pemasaran melalui pemahaman selera dan keinginan pasar, penerapan strategi produk, harga, distribusi serta promosi yang tepat dalam bentuk penyuluhan dan pendampingan.

5. Pelatihan mengenai pengelolaan (manajemen) terkait dengan fungsi-fungsi manajemen seperti dalam membuat perencanaan bisnis, laporan keuangan serta perhitungan biaya pokok produksi sehingga dapat menjalankan usaha dengan lebih profesional. Kegitan ini dilakukan dalam bentuk penyuluhan dan pendampingan.

6. Penilaian hasil. Keberhasilan pengabdian pada masyrakat ini berupa peningkatan kemampuan mitra dalam mengelola usaha dan menghasilkan dan memasarkan produk dengan cara yang lebih profesional.

\section{HASIL DAN PEMBAHASAN}

Mitra, sebelum kegiatan pengabdian diberikan, belum pernah melakukan perhitungan harga pokok produksi secara benar. Selama ini harga pokok produksi hanya didasarkan pada modal yang dikeluarkan mitra. Ketepatan dalam menghitung harga pokok produksi pada hakikatnya sangat diperlukan dalam setiap kegiatan usaha.

Mitra usaha bordir pada umumnya menetapkan harga jual produk dan jasanya hanya berdasarkan perkiraan kasar dengan dasar pengalaman mitra. Selain itu harga jual 
Lumbanraja, P. et al. Pengembangan Usaha Mikro Kecil dan Menengah (UMKM) Kerajinan Menjahit dan...

produk, khususnya jasa, sangat dipengaruhi oleh kemampuan negosiasi dari pembeli. Kondisi ini membuat perhitungan harga pokok produksi tidak akurat. Ketidakakuratan ini menghasilkan delusi nilai dari produk dan jasa yang dihasilkan, termasuk tingkat keuntungan yang diperoleh. Hal ini berdampak serius pada pengembangan usaha di masa yang akan datang.

Permasalahan yang mendasar bagi mitra adalah ketidakjelasan sistem perhitungan harga pokok produksi. Selain itu, produk mitra yang dekat dengan konteks jasa semakin menyulitkan perhitungan harga pokok produksi secara baku. Selama ini, harga pokok produksi sendiri tidak dihitung. Keuntungan dari kegiatan usaha dipersepsikan melalui upah yang diperoleh mitra. Penentuan upah itu sendiri umumnya dikuasai oleh pemborong yang mengindikasikan daya tawar rendah dari sisi mitra.

Mitra selama bertahun-tahun juga tidak memahami konsep inflasi dan dampaknya pada pengikisan nilai upah yang mereka peroleh. Seharusnya mitra mampu menyesuaikan tingkat upah yang diperolehnya berdasarkan biaya kesempatan yang terbuang serta tingkat inflasi yang terjadi. Selama bertahun-tahun pula aktivitas tersebut tidak terjadi. Sejauh ini, penetapan harga yang dilakukan mitra masih tergolong rendah untuk keterampilan yang dihasilkannya.

Solusi dari permasalahan ini adalah dengan mengajarkan konsep-konsep perhitungan harga pokok produksi serta bagaimana menentukan harga yang layak dari sebuah aktivitas jasa. Pengetahuan ini akan membantu daya tawar mitra pada konsumen pemborong sekaligus memberikan nilai nyata yang stabil pada kondisi ekonomi yang tidak stabil.

Situasi mitra pada awal kegiatan pengabdian masih belum menerapkan perhitungan harga pokok produksi secara tepat. Sering kali harga pokok produksi ini tidak dihitung karena konteks yang dilakukan adalah jasa. Perubahan yang terjadi pada mitra dirangkum dalam Tabel 5.1.

\begin{tabular}{|c|c|}
\hline \multicolumn{2}{|c|}{$\begin{array}{l}\text { Tabel } 1 \text { Perubahan Perilaku dalam } \\
\text { Perhitungan Harga Pokok Produksi }\end{array}$} \\
\hline $\begin{array}{l}\text { Kondisi Mitra Sebelum } \\
\text { Pengabdian }\end{array}$ & $\begin{array}{l}\text { Kondisi Mitra Setelah } \\
\text { Pengabdian }\end{array}$ \\
\hline $\begin{array}{l}\text { Mitra tidak melakukan } \\
\text { perhitungan harga } \\
\text { pokok produksi dalam } \\
\text { konteks jasa }\end{array}$ & 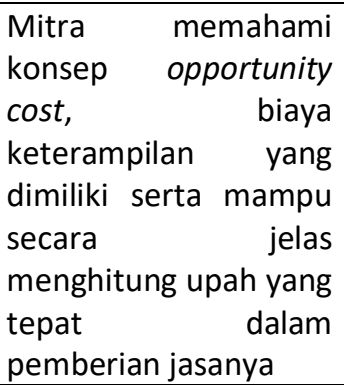 \\
\hline $\begin{array}{l}\text { Mitra tidak menetapkan } \\
\text { kenaikan upah akibat } \\
\text { ketidakstabilan ekonomi }\end{array}$ & $\begin{array}{lr}\text { Mitra mulai } & \text { memiliki } \\
\text { dasar } & \text { dalam } \\
\text { menentukan } & \text { kenaikan } \\
\text { upah r untuk } & \text { undindungi nilai } \\
\text { melil } \\
\text { usaha } & \text { yang } \\
\text { diperolehnya } & \\
\end{array}$ \\
\hline
\end{tabular}

Tabel 5.1 menunjukkan bahwa telah terjadi perubahan yang sangat fundamental dari sikap dan perilaku mitra terkait perhitungan harga pokok produksi sekaligus perhitungan konsep upah dalam pemberian jasa bordir yang diberikannya. Capaian ini adalah hasil yang sangat diharapkan dari aspek HPP.

Hasil FGD yang dilakukan memberikan kesimpulan bahwa aspek manajemen yang sangat penting dan mendesak untuk dipahami oleh mitra dan kelompoknya adalah sistem pengawasan yang efektif dalam proses kerja, kedisiplinan dalam bekerja, serta manajemen kualitas produk. Aspek-aspek ini penting dalam menciptakan keunggulan bersaing mitra di pasar luas.

Mita usaha belum mampu merancang pekerjaan dengan baik. Perencanaan kerja tidak tertata dengan baik. Penjadwalan tidak memiliki standar acuan yang jelas serta tidak ada kontrol atas kualitas produk yang dihasilkan. Kendala utama mitra adalah konflik waktu antara pekerjaan dengan rumah tangga. Kedua hal tersebut sulit dijalankan secara bersamaan.

Solusi dari permasalahan ini adalah pembiasaan diri dari mitra dan anggotanya terhadap tuntutan waktu kerja dan tanggung jawab rumah tangga. Mitra dan anggotanya harus mampu menyeimbangkan waktu antara pekerjaan dan rumah tangga. Oleh karena itu, pembinaan juga dilakukan tentang bagaimana manajemen waktu yang efektif bagi ibu-ibu 
Lumbanraja, P. et al. Pengembangan Usaha Mikro Kecil dan Menengah (UMKM) Kerajinan Menjahit dan...

dengan jadwal yang sangat padat. Hal ini adalah penanaman paradigma baru dengan efek mengubah perilaku dan pola pikir mitra. Butuh waktu yang relatif lama agar pola pikir baru terbentung secara efektif dalam diri mitra dan anggotanya.

Situasi mitra sebelum kegiatan pengabdian menunjukkan bahwa manajemen dalam operasional usaha dijalankan secara tidak sadar oleh mitra. Aspek-aspek manajemen tidak diterapkan secara efektif dan efisien sehingga belum mampu memaksimalkan potensi usaha. Perubahan yang terjadi pada mitra terkait tindakan manajemen usaha dirangkum dalam Tabel 5.2 .

Tabel 2 Perubahan Perilaku dalam Manajemen Usaha

\begin{tabular}{|c|c|}
\hline $\begin{array}{l}\text { Kondisi Mitra Sebelum } \\
\text { Pengabdian }\end{array}$ & $\begin{array}{l}\text { Kondisi Mitra Setelah } \\
\text { Pengabdian }\end{array}$ \\
\hline $\begin{array}{l}\text { Mitra secara tidak } \\
\text { sadar melakukan } \\
\text { aspek-aspek } \\
\text { manajemen }\end{array}$ & $\begin{array}{lr}\text { Mitra } & \text { mulai } \\
\text { mengetahui konsep- } & \text { keni } \\
\text { konsep dalam } & \text { manajemen dan mulai } \\
\text { secara } & \text { aktif } \\
\text { menerapkannya dalam } \\
\text { kegiatan usaha }\end{array}$ \\
\hline $\begin{array}{lr}\text { Mitra } & \text { tidak teratur } \\
\text { dalam } & \text { menjalankan } \\
\text { usaha } & \end{array}$ & $\begin{array}{l}\text { Mitra mulai berdisiplin } \\
\text { dan melakukan skedul } \\
\text { dalam membagi waktu } \\
\text { untuk usaha dan } \\
\text { keluarga. Aspek ini } \\
\text { belum efektif dilakukan } \\
\text { mitra }\end{array}$ \\
\hline $\begin{array}{l}\text { Mitra jarang } \\
\text { melakukan } \\
\text { pengembangan } \\
\text { keterampilan diri }\end{array}$ & $\begin{array}{l}\text { Secara rutin mitra } \\
\text { melakukan kegiatan } \\
\text { pengembangan } \\
\text { keterampilan. Lebih } \\
\text { lanjut mitra bersedia } \\
\text { mengajarkan } \\
\begin{array}{l}\text { keterampilan yang } \\
\text { diperolehnya kepada } \\
\text { anggota kelompok }\end{array}\end{array}$ \\
\hline
\end{tabular}

Tabel 5.2 mengindikasikan perubahan yang sukses dalam waktu relatif singkat selama pengabdian berlangsung. Aspek manajemen mulai terlihat dalam kegiatan usaha mitra. Meskipun belum efektif, mitra sudah mampu melakukan skedul dan melakukan perencanaan usaha. Diharapkan ke depannya perubahan mitra dirasakan lebih efektif lagi

Aktivitas pemasaran produk yang efektif sangat diperlukan dalam memastikan produk diterima di pasar dan sampai temat waktu pada konsumen. Hasil FGD mengindikasikan bahwa selama ini mereka sulit mengembangkan keahlian mereka karena keterbatasan mesin dan mentor yang dapat digunakan sebagai sarana berlatih. Dalam jangka panjang, kegiatan ini dapat membantu mitra mengajarkan secara mandiri anggotaanggota dalam kelompoknya yang memberikan manfaat berlipat.

Situasi saat ini dari mitra mengindikasikan bahwa mereka tidak menciptakan permintaan, namun hanya menanti pesanan datang dari pemborong. Aktivitas promosi sama sekali tidak dilakukan selain penggunaan papan nama usaha. Mitra sangat bergantung pada pemborong lain yang menggunakan jasa mereka. Kondisi ini membuat mitra tidak mandiri dalam menjalankan usaha dan sangat bergantung pada permintaan yang terjadi pada pemborong. Kegiatan penyuluhan yang dilakukan menanamkan kemandirian dalam menjalankan usaha serta bagaimana menciptakan permintaan itu sendiri. Dalam era teknologi komunikasi saat ini, mitra diminta meluangkan waktu belajar jejaring sosial sederhana. Mitra setidaknya harus mampu membuat iklan produk yang ditawarkannya secara online agar orang atau calon konsumen dapat memperoleh informasi seputar mitra. Mitra diajarkan bagaimana mengkonsep iklan yang menarik.

Saluran distribusi mitra saat ini hanyalah direct selling dimana konsumen datang langsung kepada mitra. Sebagai bentuk usaha yang dekat dengan konsep jasa, usaha bordir memang lebih efektif jika konsumen langsung bertemu dengan mitra. Akan tetapi, sembari menjaga konsep saluran distribusi yang sudah ada, mitra diajarkan untuk memanfaatkan kegiatan pameranpameran hasil produk UMKM sebagai sarana pemasaran produk. Saluran distribusi juga dapat diperkaya dengan menggunakan jasa kurir pengiriman barang sesuai dengan kesepakatan konsumen. Intinya, mitra diperkaya dengan berbagai solusi pemasaran yang dapat dilakukan agar produk tersebar lebih luas, tidak sebatas usaha lokal saja.

Aspek terakhir dari elemen pemasaran adalah harga. Mitra diajarkan bagaimana menentukan harga yang efektif. Mitra diberikan pemahaman bagaimana 
Lumbanraja, P. et al. Pengembangan Usaha Mikro Kecil dan Menengah (UMKM) Kerajinan Menjahit dan...

memposisikan diri dalam bernegosiasi harga pada konsumen serta memberikan harga yang menyenangkan bagi konsumen dan penjual. Konsep harga sangat sensitif pada selera konsumen serta daya beli konsumen. Mitra harus mampu membiasakan diri dalam melihat peluang penentuan harga yang efektif. Meskipun penetapan harga yang berbeda berdasarkan kemampuan konsumen cukup efektif dalam memasarkan sekaligus memperoleh keuntungan, mitra diminta memiliki acuan harga yang baku agar konsumen lebih mudah membuat keputusan pembeliannya. Penentuan harga sangat berkaiatan dengan kemampuan harga pokok produksi yang dibahas pada penyuluhan sebelumnya.

Dalam konteks jasa, mitra juga perlu memperhatikan bukti fisik usaha, sumber daya manusia, serta proses bordir itu sendiri. Mitra diajarkan bagaimana mengelola tempat kerja agar terlihat lebih nyaman dan asri tanpa kesan berantakan. Mitra diajarkan bagaimana keahlian pekerja dijadikan sarana memasarkan jasa bordir itu sendiri. Konsumen juga diberikan wewenang dalam melihat proses pembuatan bordir itu sendiri. Proses diharapkan menjadi baku sehingga konsumen lebih tertarik pada jasa bordir yang ditawarkan mitra.Situasi awal mitra adlaah tanpa aktivitas pemasaran. Hal ini berdampak pada rendahnya permintaan akan jasa bordir pada mitra. Mereka bergantung pada pemborong dalam menjalankan usahanya. Tanpa adanya permintaan pesanan dari pemborong, kegiatan usaha nyaris terhenti. Selain itu, sebagai usaha jasa, bentuk fisik, tata letak ruang kerja, serta media promosi masih jauh dari cukup. Mereka tidak memberhatikan kerapihan ruang kerja yang penting bagi calon pembeli.

Solusi dari permasalahan ini adalah penanaman perilaku dan pola pikir pemasaran kepada mitra. Konsep-konsep dan segala kebutuhan pemasaran efektif dan efisien diajarkan kepada mitra, namun hasil dari penanaman perilaku ini adalah perubahan perilaku yang memerlukan waktu serta pembiasaan yang relaif lama.

Kegiatan pengabdian berjalan suksen dan menunjukkan hasil yang memuaskan. Perkembangan perubahan perilaku mitra dirangkum dalam Tabel 5.3
Tabel 3 Perubahan Perilaku Pemasaran

\begin{tabular}{|c|c|}
\hline $\begin{array}{l}\text { Kondisi Mitra Sebelum } \\
\text { Pengabdian }\end{array}$ & $\begin{array}{l}\text { Kondisi Mitra Setelah } \\
\text { Pengabdian }\end{array}$ \\
\hline $\begin{array}{l}\text { Mitra tidak } \\
\text { menggunakan saluran } \\
\text { distribusi dan promosi }\end{array}$ & $\begin{array}{l}\text { Mitra mulai berencana } \\
\text { mengikuti pameran } \\
\text { hasil usaha UMKM yang } \\
\text { diadakan pemerintah. } \\
\text { Meskipun sejauh ini } \\
\text { masih rencana, namun } \\
\text { mereka siap } \\
\text { melaksanakannya jika } \\
\text { ada kesempatan }\end{array}$ \\
\hline $\begin{array}{lr}\text { Mitra } & \text { hanya } \\
\text { menunggu } & \text { pesanan } \\
\text { datang } & \text { dari } \\
\text { pemborong } & \end{array}$ & $\begin{array}{l}\text { Mitra secara pro-aktif } \\
\text { menciptakan } \\
\text { permintaan dengan } \\
\text { menggunakan media } \\
\text { promosi seperti banner }\end{array}$ \\
\hline $\begin{array}{lr}\text { Mitra } & \text { tidak } \\
\text { memperdulikan } & \text { fisik } \\
\text { ruang kerja } & \end{array}$ & $\begin{array}{l}\text { Ruang kerja lebih } \\
\text { tertata rapi dengan } \\
\text { tidak banyak berserakan } \\
\text { kain-kain } \\
\text { proccess }\end{array}$ \\
\hline
\end{tabular}

Tabel 5.3 mengindikasikan bahwa perubahan positif sudah mulai terjadi dari situasi mitra dalam aspek pemasaran. Mereka mulai aktif dalam menciptakan permintaan daripada sekedar menunggu pesanan datang.

Secara umum, pelaksanaan kegiatan pengabdian yang dilakukan berlangsung dengan sukses. Meskipun demikian, evaluasi tetap dilakukan untuk peluang perbaikan dan pengembangan di kemudian hari. Pada pelaksanaan penyuluhan, meskipun pada awalnya waktu pertemuan telah disepakati dengan mitra pemilik usaha beserta anggota kelompoknya, mitra harus selalu di-follow up hingga hari pertemuan dilaksanakan. Alasan utama dari tindakan ini adalah mitra yang umumnya ibu rumah tangga sebagai status utama. Status ibu rumah tangga harus mengedepankan kepentingan rumah tangga sebelum dapat mengikuti dengan lancar proses pengabdian yang dilakukan. Status tersebut juga membuat mereka tidak fokus pada satu jadwal yang ditentukan. Oleh karena itu, di masa yang akan datang kesepakatan waktu ini harus memperhatikan sudut pandang seluruh mitra dan anggotanya agar kelangsungan pengabdian tetap efektif.

Pengabdian yang dilakukan melakukan bimbingan kepada mitra setelah selesai memberikan penyuluhan yang mendidik mitra terkait aspek manajemen, 
Lumbanraja, P. et al. Pengembangan Usaha Mikro Kecil dan Menengah (UMKM) Kerajinan Menjahit dan...

pemasaran, serta harga pokok produksi. Dalam hal ini, mitra diharapkan pro-aktif dalam memaksimalkan potensi pengabdian. Akan tetapi, dalam situasi tertentu tim pengabdi harus lebih memotivasi mitra agar proses pendampingan berjalan efektif.

Mitra berpartisipasi dengan baik selama proses pengabdian berjalan. Akan tetapi mitra yang pada umumnya merupakan ibu rumah tangga memiliki konflik waktu dalam menjalankan proses pengabdian secara efektif. Selain konflik waktu, mitra menunjukkan antusiasme yang tinggi dalam seluruh rangkaian proses pengabdian, mulai dari keterbukaan masalah dalam diskusi kelompok, antusiasme dalam penyuluhan, aktif dalam pelatihan, serta mau bertanya jika ada masalah yang dihadapi dalam pengembangan usaha terkait kegiatan pengabdian. Konflik waktu membuat mereka terlambat dalam mengikuti rangkaian kegiatan, namun rekan mitra mau membantu ketinggalan mitra lainnya.

\section{KESIMPULAN}

Rangkaian aktivitas pengabdian yang dilakukan memberikan teknologi tepat guna bagi usaha bordir dalam bentuk efektivitas dan efisiensi produksi, teknik pengembangan kualitas produk, kemampuan pemasaran dan daya saing, serta kemampuan manajemen usaha. Selain itu, mitra dibekali dengan kemampuan menghitung harga pokok produksi serta pemasaran yang efektif dan efisien untuk membantu penciptaan permintaan dan keakuratan nilai hasil usaha. Kegiatan pengabdian ini juga menunjukkan kesimpulan bahwa:

1. Masyarakat Indonesia adalah masyarakat yang mau belajar dan mampu meningkatkan kapabilitasnya jika diajari. Pengelola UMKM terkadang memiliki latar belakang pendidikan yang tidak sesuai dengan bidang keahliannya, namun dengan perhatian kita bersama mereka dapat memaksimalkan potensi usaha yang dijalaninya.

2. Kendala fasilitas dan pengetahuan menjadi akar permasalahan pengembangan usaha dari UMKM mitra. Oleh karena itu, penting bagi kita semua untuk membina dan mendukung kegiatan UMKM sehingga mereka bisa terus tumbuh dan berkembang mendorong perekonomian bangsa.

\subsection{Saran}

1. Kegiatan pengabdian maysakat dalam kesempatan kali ini dirasakan cukup singkat. Masih banyak rencana kegiatan yang belum terealisasi secara efektif. Sebagai contoh, tim pengabdian masih memerlukan waktu yang lebih lama agar evaluasi kemajuan mitra dirasakan lebih baik lagi. Dengan demikian, sangat disarankan untuk mengevaluasi kembali kebijakan lama waktu pengabdian yang diberikan.

2. Banyak sekali usaha UMKM yang memerlukan kegiatan-kegiatan pengabdian yang dilakukan seperti pada usaha Bordir ini. Secara umum mereka memerlukan pengetahuan manajemen secara mendasar agar dapat meningkatkan efektivitas dan efisiensi usaha. Oleh karena itu, kegiatan pengabdian ini perlu dilestarikan, khususnya dalam aspek pembangunan kompetensi UMKM yang merupakan pemberi sumbangan terbesar dalam pembangunan Indonesia melalui sumbangan pendapatan domestik bruto usaha.

3. Ketidakmampuan manajemen yang baik dari mitra dikarenakan pengetahuan yang kurang dalam hal ilmu dan konsepkonsep manajemen itu sendiri. Oleh karena itu, kerjasama dalam mendidik mitra atau pengusaha UMKM lain sangat disarankan untuk diajukan dan diimplementasikan.

\section{REFERENSI}

Beaver, Graham. 2002. Small Business, Entrepreneurship and Enterprise Development. New York: Prentice Hall

Dessler, Gary. 2011. Human Resource Management, $12^{\text {th }}$ Edition. New York: Prentice Hall

Kotler, Philip dan Kevin Lane Keller. 2012. Marketing Management, 14th Edition. New Jersey: Prentice Hall.

Mondy, R Wayne. 2014. Human Resource Management, $13^{\text {th }}$ Edition. New York: Prentice Hall 
Lumbanraja, P. et al. Pengembangan Usaha Mikro Kecil dan Menengah (UMKM) Kerajinan Menjahit dan...

Robbins, Stephen P dan Timothy A Judge.

Edition). New Jersey: Pearson Education

2013. Organizational Behaviour (15th 